\title{
The Cultural Centre of the Monastery of Bouake
}

THE Cultural Centre of the Monastery of Bouaké (Ivory Coast) was inaugurated in January 1962 by an International Meeting on the theme of "Tradition and Modernism in Africa', the proceedings of which were published as a special issue of 'Images de Toumliline'. A series of four international sessions has been organized with the financial assistance of the Ford Foundation and the French Ministry of Co-operation to study religious problems. They will be held at the Monastery of Bouaké at the following times:

October 1962: African primitive religions

April $x_{96}$ : Islam in Africa

October 1963: Syncretisms in Africa

April 1964 : Christianity in Africa

The first session, which took place from is to 20 October, was attended by some twenty anthropologists, including Madame Denise Paulme, M. Michel Leiris, M. Pierre Verger, Professor William Bascom, Professor Luc de Heusch, Mr. Hans Himmelheber, and others. Further information about the Centre and its activities may be obtained from the R.P. Placide Pernot, O.S.B., Monastère de Toumliline, Azrou, Morocco.

Sir George Tomlinson, K.C.M.G., C.B.E.

WE regret to announce the death of Sir George Tomlinson, who served as a member of the Interim Committee of the Institute during the war, and subsequently as a member of the Executive Council until 1949 .

Most of his overseas service career was devoted to furthering African education. After four years as an administrative officer in Nigeria, he was appointed Director of Education in the Gold Coast in 191 $x$, where he remained until 1928. From 1930 to 1939 he was Assistant Under-Secretary of State at the Colonial Office, where he held the post of Head of the Personnel Division.

\section{Professor Melville J. Herskovits}

$W_{E}$ deeply regret to record the death of Professor Melville J. Herskovits, of Northwestern University, on 25 February 1963. An appreciation of the great contribution to African Studies made by Professor Herskovits and of his valuable services to the Institute as a member of its Executive Council since 1947 will be given in the July number of Africa. 